\title{
Wyższa Szkoła Ekologii i Zarządzania w Warszawie - jubileusz 25-lecia działalności 1995-2020
}

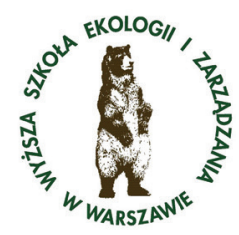

\section{Prezydent Wyższej Szkoły Ekologii i Zarządzania profesor dr hab. inż. Jan Misiak}

Wyższa Szkoła Ekologii i Zarządzania powstawała w okresie, kiedy zmiany w systemie gospodarczo-społecznym w naszym kraju weszły w stadium intensywnego rozwoju. Kształtujący się wolny rynek zrodził zapotrzebowanie na usługi edukacyjne, świadczone do $1990 \mathrm{r}$. wyłącznie przez szkoły państwowe.

W tym właśnie okresie, w odpowiedzi na zwiększone zapotrzebowanie na fachowców z wyższym wykształceniem, zrodziła się myśl założenia WSEiZ.

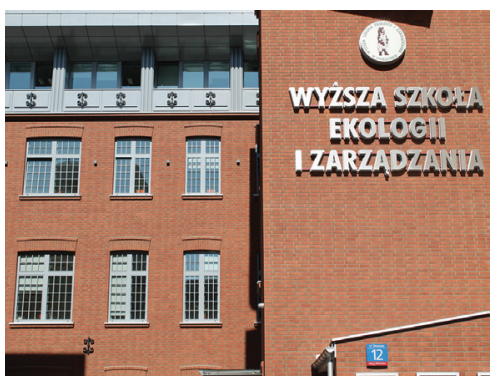

Ówczesny rynek pracy chłonął ludzi z dobrym przygotowaniem menedżerskim, fachowców od zarządzania. To dlatego powstające w tym okresie szkoły wyższe oferowały kandydatom na studia głównie kierunki związane z zarządzaniem.

Rodząca się we mnie myśl założenia szkoły uwzględniała ten element, ale jednocześnie, jako wieloletni nauczyciel akademicki i kierujący szkołami wyższymi, zdawałem sobie sprawę z faktu, że najbardziej efektywne wykształcenie, to wykształcenie interdyscyplinarne. Dlatego też pierwsze kierunki kształcenia, od których WSEiZ rozpoczęła działanie, to Zarządzanie i Marketing oraz Ochrona Środowiska - ściśle ze sobą połączone.

Występując 25 lat temu z wnioskiem o pozwolenie na prowadzenie uczelni, prezentowałem pogląd kształcenia kompleksowego ze szczególnym uwzględnieniem ochrony środowiska, przewidując, że ten kierunek kształcenia będzie w przyszłości, zwłaszcza po wejściu do Unii Europejskiej, szeroko akceptowany przez kandydatów na studia. Koncepcja kształcenia, którą wówczas opracowałem, to kształcenie ekonomiczno-przyrodniczo-techniczne. Ta koncepcja zyskała uznanie i zaowocowała rozwojem uczelni aż po dzień dzisiejszy.

WSEiZ to Uczelnia, która jako jedna z pierwszych uczelni niepublicznych ,postawiła” na kierunki tech-

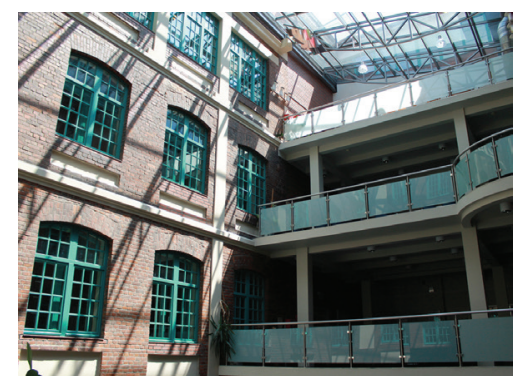


niczne. W WSEiZ bowiem nie boimy się wyzwań i przeciwności! Świadczy o tym chociażby fakt, iż mimo niżu demograficznego i gwałtownego spadku liczby chętnych na studia, m.in. na Ochronę Środowiska, nie zaprzestaliśmy kształcenia na jednym z naszych flagowych kierunków. Opłaciło się! W tym roku akademickim po raz pierwszy od kilku lat wzrosła liczba kandydatów na ten, tak ważny dla przyszłości nas wszystkich kierunek. Oprócz wspomnianej Ochrony Środowiska, jako jedyna uczelnia niepubliczna w regionie, proponujemy także inne kierunki techniczne, takie jak Zarządzanie i Inżynieria Produkcji czy Mechanika i Budowa Maszyn.

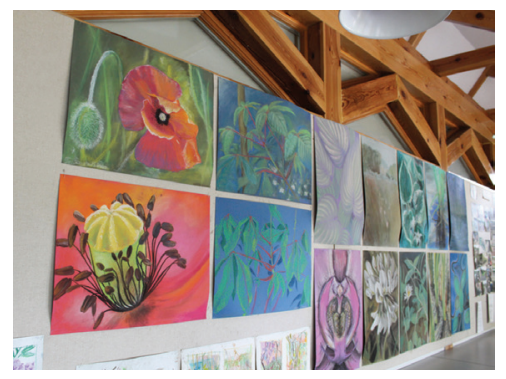

Na Wydziale Architektury, jako jedyni w Polsce proponujemy kandydatom możliwość kształcenia na wszystkich kierunkach związanych z dziedziną nauk inżynieryjno-technicznych i dziedziną sztuki czyli: Architekturze, Architekturze Krajobrazu, Architekturze Wnętrz, Budownictwie czy Wzornictwie.

Warto też wspomnieć, że w 2015 r. państwa członkowskie Unii Europejskiej oraz Komisja Europejska zaakceptowały wniosek notyfikacyjny dotyczący kierunku Architektura. Dzięki temu dyplom ukończenia studiów na kierunku Architektura w WSEiZ jest podstawą do automatycznego uznania kwalifikacji zawodowych i otwiera drogę do pełnego uzyskania uprawnień do wykonywania zawodu architekta w państwie członkowskim Unii Europejskiej.

Proponowane na poszczególnych kierunkach specjalności rozwijamy tak, by wiedza na nich zdobywana była jak najbardziej praktyczna - dlatego też na kierunkach: Architektura Krajobrazu, Architektura Wnętrz, Budownictwo, Wzornictwo, Ochrona Środowiska, Zdrowie Publiczne, Mechanika i Budowa Maszyn, Zarządzanie oraz Zarządzanie i Inżynieria Produkcji zmieniliśmy programy kształcenia z ogólnoakademickich na praktyczne. W pla-


nach mamy także poszerzenie oferty edukacyjnej o kolejne studia II stopnia, w najbliższym czasie na kierunkach Budownictwo i Architektura Krajobrazu. Nieustająco badamy również potrzeby uruchomienia nowych studiów podyplomowych. Obecnie, w ofercie edukacji podyplomowej, proponujemy kierunki z zakresu Architektury, Budownictwa, Ochrony Środowiska czy Zarządzania, takie jak:

- Rysunek i Malarstwo,

- BIM - Building Information Modeling,

- Zarządzanie Drogami - utrzymanie i eksploatacja,

- Odnawialne Źródła Energii, Gospodarka Wodna i Odpadowa,

- Menadżer Energii, 
- Akademia Zarządzania Kulturą,

- Zarządzanie Transportem i Logistyka,

- Zarządzanie Przedsiębiorstwem Produkcyjnym.
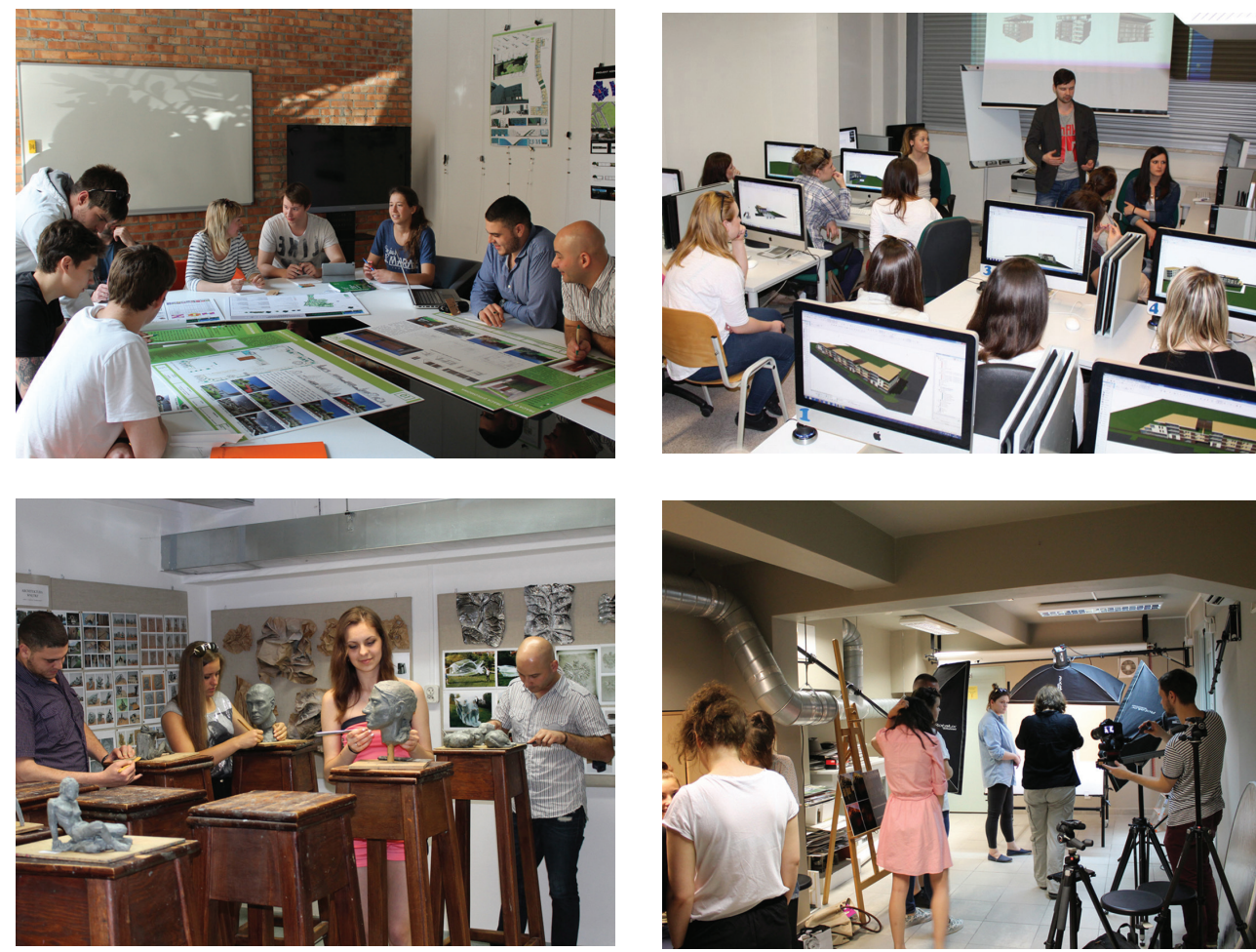

WSEiZ rozwija się również poprzez wykorzystanie funduszy unijnch. W tym roku pozyskaliśmy dofinansowanie z Programu Operacyjnego Wiedza Edukacja Rozwój m.in. na utworzenie nowego kierunku studiów - Informatyki. Dzięki pozyskanemu wsparciu możliwy był zakup nie tylko sprzętu komputerowego i oprogramowania do pracowni dla nowego kierunku, ale przede wszystkim dofinansowanie czesnego dla studentów tego kierunku. Studenci kierunku Informatyka, w zależności od formy studiów (stacjonarna, niestacjonarna) korzystają z obniżki czesnego od 50 do nawet $80 \%$. Projekt obejmie też studentów innych kierunków w WSEiZ, dla których przewidziano płatny program stażowy oraz dodatkowe kursy i szkolenia podnoszące ich kompetencje i ułatwiające start na rynku pracy.

W WSEiZ dbamy, aby edukacja opierała się nie tylko na przekazywaniu wiedzy teoretycznej, ale także na profesjonalnym przygotowaniu do wykonywania przyszłego zawodu. Cel ten możemy osiągnąć dzięki umiejętnościom praktycznym kadry akademickiej, wpływowi pracodawców na programy studiów i jakości kształcenia zgodnej ze standardami europejskimi. W WSEiZ pracuje ponad 300 specjalistów z różnych dziedzin. Nasi wykładowcy to nie tylko pracownicy naukowi, ale także praktycy posiadający doświadczenie biznesowe. Dzię- 

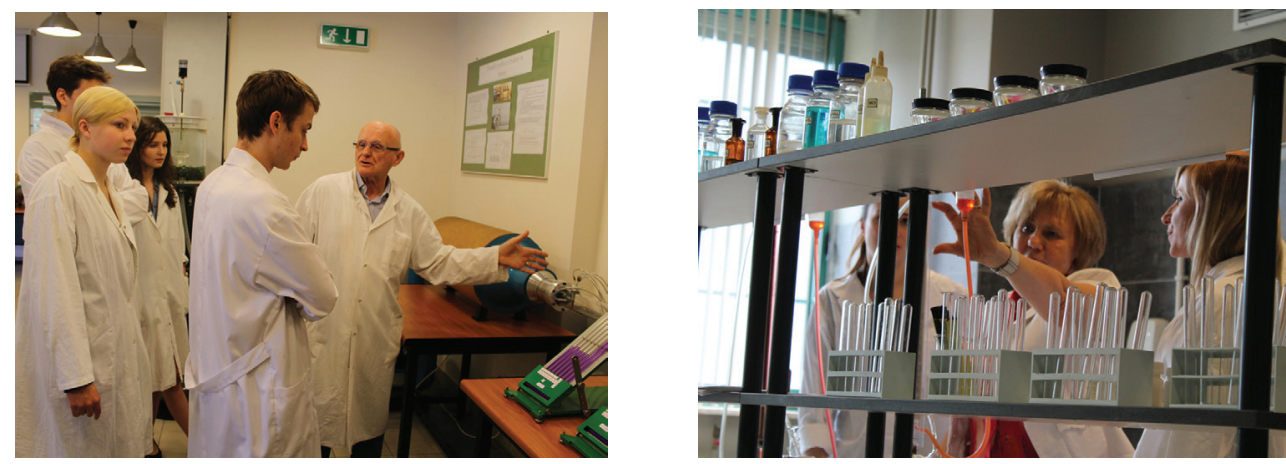

ki wiedzy wykładowców oraz zrzeszonych w Wydziałowych Radach Pracodawców przedsiębiorców, z którymi konsultujemy programy studiów wiemy, że kształcenie w WSEiZ ma charakter interdyscyplinarny, łączy teorię z praktyką. Natomiast dzięki temu, że studia prowadzone są w trybie projektowym, uczą studentów samodzielności i podejmowania odpowiedzialnych decyzji. O wysokim poziomie kształcenia w Wyższej Szkole Ekologii i Zarządzania świadczy również fakt, iż wszystkie kierunki studiów w WSEiZ, akredytowane przez Polską Komisję Akredytacyjną zostały ocenione pozytywnie, a współpraca z otoczeniem społeczno-gospodarczym na kierunkach Architektura i Budownictwo oceniona została wyróżniająco. Warto też wspomnieć, że Wydział Architektury otrzymał pozytywną ocenę instytucjonalną dotyczącą jakości kształcenia.

WSEiZ intensywnie współpracuje nie tylko z otoczeniem gospodarczym w ramach Wydziałowych Rad Pracodawców, ale także realizuje kilkanaście umów z różnymi jednostkami samorządu terytorialnego z otoczenia stolicy i nie tylko. Gminy, z którymi w ostatnim czasie podpisaliśmy porozumienia o współpracy to Izabelin, Jabłonna, Kobyłka oraz Ożarów. Do podmiotów wspierających rozwój WSEiZ należą także instytucje kultury, m.in. Muzeum Zamoyskich w Kozłówce, Muzeum Nadwiślańskie w Kazimierzu Dolnym czy też Muzeum Sportu i Turystyki w Warszawie, w którym już po raz czwarty odbyła się wystawa prac studentów z przedmiotu Olympic Architecture. Tematem ekspozycji było Mobilne Muzeum Igrzysk Olimpijskich. Prezentowane projekty wykonane zostały pod kierunkiem dra inż. arch. Marcina Zabłockiego i prof. Wojciecha Zabłockiego - architekta i medalisty olimpijskiego.

Staramy się także, aby nasi studenci zdobywali doświadczenie międzynarodowe, dlatego też stale rozwijamy współpracę międzynarodowa np. w ramach programu Erasmus Plus. W ostatnim czasie, w ramach wymiany studenckiej gościliśmy studentów z: Turcji, Portugalii, Hiszpanii, Włoch, Serbii, Brazylii, Kazachstanu i Ukrainy. Studenci WSEiZ wyjechali na studia lub praktyki zawodowe do Portugalii, Wielkiej Brytanii, Francji, Hiszpanii, Niemiec, Belgii i Włoch. Naszą Uczelnię odwiedzają także nauczyciele akademiccy i pracownicy admini-

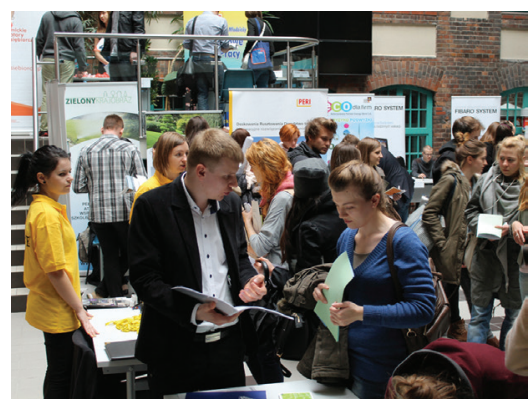


stracyjni z uczelni partnerskich. W czerwcu byliśmy organizatorem Staff Week, kilkudniowego spotkania, podczas którego uczestnicy wymieniali się doświadczeniami dotyczącymi różnych aspektów funkcjonowania uczelni, a przede wszystkim działaniom służącym podnoszeniu jakości kształcenia.

WSEiZ po 25 latach istnienia wyrobiła sobie markę jednej z najlepszych niepublicznych uczelni techniczno-artystycznych w Polsce. Świadczą o tym m.in. przyznane nam przez te ćwierć wieku liczne nagrody i wyróżnienia, w tym: dwukrotnie przyznany WSEiZ tytuł Uczelni Roku, czterokrotnie Uczelnia nagrodzona została Medalem Europejskim, otrzymaliśmy certyfikat Lidera Aktywności Inwestycyjnej, wyróżnienie w konkursie na Najbardziej Innowacyjną i Kreatywną Uczelnię w Polsce w Tworzeniu Perspektyw Zawodowych, certyfikat Uczelni Liderów. WSEiZ jest także wielokrotnym laureatem certyfikatu DOBRA UCZELNIA DOBRA PRACA oraz kilkukrotnie uzyskaliśmy wyróżnienie znakiem jakości WIARYGODNA SZKOŁA. Z nagród przyznanych w ostatnich dwóch latach warto wymienić certyfikat Lider Jakości Kształcenia dla kierunku Mechanika i Budowa Maszyn, certyfikat Studia z przyszłością dla kierunku Architektura, Polską Nagrodę Inteligentnego Rozwoju czy wyróżnienie Eko-Inspiracja dla Koła Naukowego Ekologów WSEiZ.

W minionym roku akademickim Wydział Architektury WSEiZ otrzymał prestiżowe wyróżnienie Builder for the Future, przyznawane przez profesjonalne czasopismo branży architektoniczno-budowlanej Builder. W nielicznym gronie uhonorowanych wydziałów architektury i budownictwa polskich uczelni byliśmy jedynym przedstawicielem uczelni niepublicznych.

Naszym sukcesem - jako Uczelni - jest stworzenie nowoczesnej, przystosowanej do potrzeb osób niepełnosprawnych bazy dydaktyczno-administracyjnej, na którą składają się budynki zlokalizowane w centrum Warszawy. Na bazę dydaktyczno-administracyjną WSEiZ składają się siedziba Uczelni przy ul. Olszewskiej 12 (Warszawa, dzielnica Mokotów), kompleks budynków przy ul. Rejtana 16 (Warszawa, dzielnica Mokotów) budynek przy ul. Grójeckiej 128 (Warszawa, dzielnica Ochota) oraz nieruchomości w miejscowości Klaudyn-Laski k. Warszawy przy ul. Klaudyńskiej 33, na terenie której funkcjonuje Terenowa Stacja Ochrony Przyrody i Krajobrazu WSEiZ, gdzie prowadzone są m.in. zajęcia terenowe i praktyki na kierunkach: Architektura Krajobrazu i Ochrona Środowiska.

Zakładając WSEiZ chciałem stworzyć nowoczesny i dynamiczny ośrodek akademicki i to mi się udało, ale największym osiągnięciem WSEiZ są jej studenci, absolwenci i pracownicy. 


\section{JM Rektor Wyższej Szkoły Ekologii i Zarządzania prof. WSEiZ Monika Madej}

Rok akademicki 2019/2020 jest dla Wyższej Szkoły Ekologii i Zarządzania rokiem szczególnym, gdyż weszliśmy w ćwierćwiecze istnienia naszej uczelni.

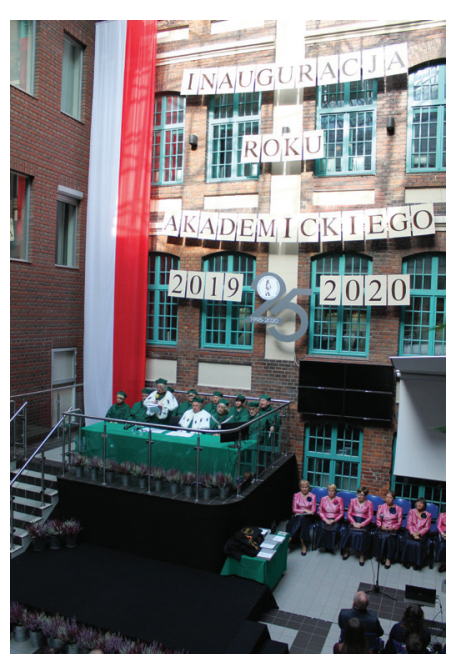

Najważniejsze ubiegłoroczne wydarzenia z życia WSEiZ, krótko charakteryzują dwadzieścia pięć lat naszej działalności.

Zacznijmy od sukcesów Uczelni oraz osiągnięć jej wykładowców i studentów w minionym roku akademickim.

W 2018 r. nasza uczelnia, już po raz drugi, została laureatem Polskiej Nagrody Inteligentnego Rozwoju pod patronatem Prezesa Urzędu Patentowego RP. Zostaliśmy nagrodzeni w kategorii Uczelnia Przyszłości za najwyższą jakość kształcenia studentów przy wykorzystaniu nowoczesnej bazy dydaktycznej. Od 2016 r. laureatami nagrody zostają organizacje, które w swojej działalności wykazują się ukierunkowaniem na przyszłość, których projekty i przedsięwzięcia charakteryzują się innowacyjnością i są przykładami zrównoważonego i inteligentnego rozwoju.

Ponadto, w roku ubiegłym WSEiZ wraz z agencją rekrutacyjną Polonia Kultur z Turcji otrzymała, również po raz drugi, nagrodę przyznaną rzez NET AGENT AWARD za najlepszy wynik w rekrutacji studentów obcokrajowców. A w konkursie EDUinspiracje w sektorze szkolnictwo wyższe, który odbył się pod hasłem „Podziel się sukcesem” uzyskaliśmy nominację za „mobilność studentów i pracowników w Programie Erasmus”. Było to dla nas duże wyróżnienie, zwłaszcza, że wśród nominowanych byliśmy jedyną uczelnią niepubliczną.

Kolejny nasz sukces to prestiżowe wyróżnienie Builder for the Future dla wydziału Architektury WSEiZ przyznane przez profesjonalne czasopismo z branży budowlanej Builder. W nielicznym gronie uhonorowanych najlepszych wydziałów architektury i budownictwa polskich uczelni, byliśmy jedynymi przedstawicielami uczelni niepublicznych.

Mgr inż. arch. krajobrazu Jakub Botwina, wykładowca na kierunku architektura krajobrazu, wraz z zespołem zdobył I miejsce w konkursie zorganizowanym przez Urząd miasta Bielsko-Biała i Stowarzyszenia Architektów Polskich na opracowanie koncepcji urbanistyczno-architektonicznej zagospodarowania rejonu placu Fabrycznego w Bielsku-Białej.

W lutym 2019 r. zostały zakwalifikowane i zaprezentowane na wystawie New Polish Poster w Glasgow 2 plakaty mgra sztuki Jana Dhiel-Michałowskiego, wykładowcy WSEiZ na kierunku Wzornictwo. New Polish Poster jest niezależnym projektem kuratorskim Igi Zwolińskiej, który ma na celu promocję polskiej sztuki plakatowej, grafiki i designu za granica. Wystawione prace oscylowały wokół tematu tolerancji i akceptacji. 
Kibicujemy i wspieramy także studentów i absolwentów w ich drodze do sukcesów zawodowych. W konkursie ogłoszonym przez gminę Jabłonna na opracowanie koncepcji zagospodarowania przestrzennego centrum Jabłonny, I miejsce i nagrodę pieniężną komisja oceniająca przyznała Pani inż. arch. Adriannie Pianowskiej i Panu inż. arch. Damianowi Urbanek, studentom studiów magisterskich na kierunku Architektura. W minionym roku, także absolwent kierunku Architektura mgr inż. Volodymyr Melymuka otrzymał wyróżnienie honorowe w ogólnopolskim konkursie „Dyplom z programem ARCHICAD”" za pracę dyplomową "Centrum kultury wraz z muzeum w środowisku miejskim w Warszawie”. W konkursie, w którym zgłoszono aż 266 prac inżynierskich i magisterskich był on jedynym nagrodzonym absolwentem uczelni niepublicznej.

Nagrody za najlepsze projekty muzeum Norwida w Dębinkach otrzymali studenci i wykładowcy studiów magisterskich, także kierunku Architektura. Nagrodzone zostały trzy propozycje. Do opracowania projektów naszych studentów zaprosiła Fundacja Museion Norwid.

Ważna jest dla nas, jako uczelni techniczno-artystycznej, działalność kulturalna. Wspieramy naszych wykładowców i studentów w zaistnieniu na kulturalnej mapie miasta i poszerzeniu grona ich odbiorców, m.in. poprzez organizowanie wystaw. W ubiegłym roku zorganizowaliśmy ich kilkanaście. Autorami prac byli studenci, wykładowcy oraz zaprzyjaźnieni z uczelnią twórcy, a ich prace były prezentowane nie tylko w Galerii WSEIZ. Wystawa pt. „Element Szczególny w Otoczeniu - Ślady”, prezentująca efekt prac pleneru fotograficznego w Zakopanem, została przedstawiona w październiku 2018 r. w Kownie na Litwie podczas międzynarodowej konferencji Landscape Creation Process. To już drugi raz, kiedy poplenerowa wystawa konferencji KRAJart prezentowana była poza granicami Polski.

Natomiast już po raz czwarty, w ramach współpracy z Muzeum Sportu i Turystyki w Warszawie, odbyła się wystawa prac studenckich z przedmiotu Olympic Architecture, tym razem tematem było Mobilne Muzeum Igrzysk Olimpijskich. Prace wykonane były pod kierunkiem dra inż. arch. Marcina Zabłockiego i prof. Wojciecha Zabłockiego.

Kolejną wystawa, o której chciałabym wspomnieć, była prezentacja niezwykle oryginalnych makiet architektonicznych wykonanych z klocków lego. Wystawa promowała nowe

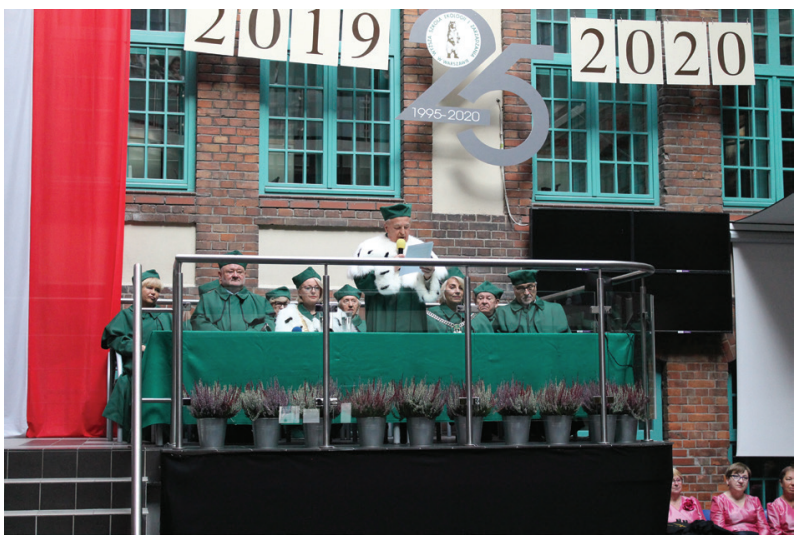
koło naukowe architektoniczno-urbanistyczne ARCHIBRICK założone $\mathrm{z}$ inicjatywy studentów studiów magisterskich inż. arch. Anny Miłosz i inż. arch. Piotra Karlickiego. Opiekunami koła są wykładowcy mgr. inż. arch. Izabela Sobierajska i mgr inż. arch. Karol Szparkowski.

Dużym zainteresowaniem cieszyła się także wystawa pt. „Architektura Malowana" profesora Wojciecha Zabłockiego, 
na której zaprezentowane zostały rysunki, wykonane różnymi technikami, przedstawiające obiekty architektoniczne zaprojektowane przez naszego wybitnego wykładowcę w trakcie jego wieloletniej kariery zawodowej.

Z wystaw zaprzyjaźnionych z Uczelnią twórców warto przywołać prezentację prac wybitnych artystów zrzeszonych w Stowarzyszeniu Akwarelistów Polskich. Na wystawie pt. „Akwarela” można było podziwiać aż 80 fantastycznych dzieł, które tylko pierwszego dnia obejrzało ponad 100 osób.

Inne wydarzenia, które miały miejsce w WSEiZ, i o których warto wspomnieć, to udział po raz kolejny w warszawskim festiwalu nauki i nocy muzeów oraz zorganizowany przez czasopismo Builder bardzo interesujący Dzień Młodego Architekta. W jego trakcie odbyły się liczne prelekcje, warsztaty a także konsultacje branżowe. Uczestnikami byli studenci architektury wszystkich warszawskich uczelni oraz uczniowie 2 techników architektoniczno-budowlanych.

Niestety, w tym roku grono akademickie opuścili wykładowcy, którzy współtworzyli Wydział Architektury naszej Uczelni i przez dekady z oddaniem, pasją i zaangażowaniem wykształcili wiele pokoleń architektów. Podczas uroczystej inauguracji roku akademickiego 2019/2020 Statuetkę Niedźwiedzia, Nagrodę Prezydenta WSEiZ otrzymali wybitni architekci - prof. dr hab. inż. architekt Witold Werner oraz prof. dr hab. inż. architekt Wojciech Zabłocki. Nagroda wręczona została jako podziękowanie za wieloletni wkład pracy i wysiłek na rzecz rozwoju Wyższej Szkoły Ekologii i Zarządzania w Warszawie.

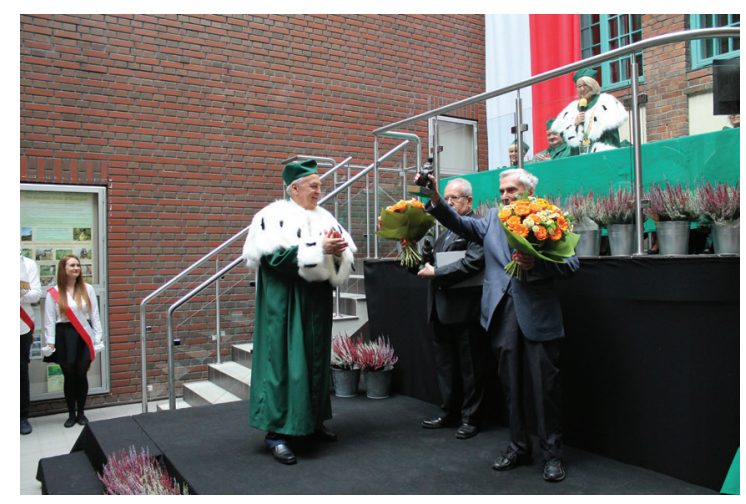

Wiele naszych osiągnięć zawdzięczamy stałej i intensywnej współpracy z firmami i instytucjami działającymi w Radach Pracodawców, funkcjonujących przy naszych wydziałach. Z roku na rok grono członków Rad poszerza się o kolejne przedsiębiorstwa, dzięki czemu mamy szansę wspólnie podejmować nowe wyzwania, przyczyniające się do rozwoju Uczelni. Wśród nowych członków Rad Pracodawców powitaliśmy w tym roku firmę telekomunikacyjną Orange, Warszawską Izbę Gospodarczą oraz Technikum nr 7 im. Stanisława Wysockiego (dawną Kolejówkę). Natomiast do grupy współpracujących z WSEiZ podwarszawskich gmin dołączyła gmina Tarczyn. 




Miniony rok akademicki to także dalszy rozwój współpracy międzynarodowej, m.in. programu Erasmus Plus. W ramach wymiany studenckiej studia w WSEiZ realizowało 35 studentów z: Turcji, Portugalii, Hiszpanii, Włoch, Serbii, Brazylii, Kazachstanu i Ukrainy. Natomiast 17 studentów WSEiZ wyjechało na studia lub praktyki zawodowe do Portugalii, Wielkiej Brytanii, Francji, Hiszpanii, Belgii, Niemiec i Włoch. Ponadto 19 wykładowców i pracowników z uczelni partnerskich odwiedziło naszą uczelnię, a 11 naszych nauczycieli i pracowników administracji wyjechało do uczelni za granicą. W czerwcu byliśmy organizatorem Staff Week, w którym udział wzięli goście z 5 krajów. W ciągu kilku dni uczestnicy wymieniali się doświadczeniami dotyczącymi różnych aspektów funkcjonowania uczelni, a przede wszystkim działaniami służącym podnoszeniu jakości kształcenia.

Rok ubiegły był dla nas czasem bardzo wytężonej pracy, w związku z przygotowaniami do wdrożenia nowej ustawy Prawo o Szkolnictwie Wyższym i Nauce, tzw. Konstytucji dla nauki, czyli ustawy 2.0. Musieliśmy opracować nowy statut uczelni, wszystkie regulaminy i zarządzenia zgodnie z wymogami nowych przepisów. Także programy kształcenia przeszły gruntowne zmiany, zostały zwiększone liczby godzin zajęć ćwiczeniowych i projektowych oraz obowiązkowych praktyk, tak, aby dostosować je do praktycznego profilu kształcenia, który od października zaczął obowiązywać na wszystkich kierunkach studiów, rozpoczynających się od I semestru.

W roku akademickim 2018/19 przeszliśmy aż 3 akredytacje Polskiej Komisji Akredytacyjnej. Odbyły się one na kierunku Budownictwo, Architektura i Architektura Krajobrazu. Na kierunkach Architektura i Budownictwo otrzymaliśmy ocenę pozytywna, wraz z wyróżnieniem Wydziału za współpracę z otoczeniem społeczno-gospodarczym. Bardzo dziękujemy wszystkim firmom i instytucjom, które wspierają kształcenie na obu kierunkach. Ich zaangażowanie zostało docenione przez PKA.

Kolejnym sukcesem zakończyła się dla naszej uczelni całkowicie nowa w polskim prawie procedura uzyskiwania pozwolenia na kształcenie na studiach cudzoziemców. Po przeprowadzonej przez Straż Graniczną kontroli uczelni, pod kątem studiowania w WSEiZ cudzoziemców, we wrześniu otrzymaliśmy od Ministerstwa Spraw Wewnętrznych stosowny dokument, który umożliwi nam dalsze rozwijanie umiędzynarodowienia studiów.

Od wielu lat pozyskujemy także środki z funduszy UE na różnego typu przedsięwzięcia. Projekt „Nowoczesny Program Rozwoju WSEiZ” otrzymał dofinansowanie ze środków unijnych w konkursie ogłoszonym przez NCBiR. W związku z tym, w latach 2019-2023, będziemy realizować szereg działań na łączną kwotę 2,5 mln. Największym zadaniem tego 
projektu jest uruchomienie na kierunku Informatyka studiów I stopnia i przeprowadzenie jednego pełnego cyklu kształcenia. Na prowadzenie tego kierunku WSEiZ otrzymała pozwolenie z Ministerstwa Nauki i Szkolnictwa Wyższego w lipcu 2019 r. Rekrutacja na ten kierunek została przeprowadzona z sukcesem, studia stacjonarne rozpocznie 30 osób, a niestacjonarne 60 osób. Studenci, będą mieli dofinansowane czesne w wysokości 50\% na studiach stacjonarnych i 80\% na studiach niestacjonarnych. Zajęcia praktyczne będą odbywały się w nowoczesnych laboratoriach komputerowych ze sprzętem, na zakup którego WSEiZ otrzymała środki z projektu.

Dotychczasowe osiągnięcia naszej uczelni pozwalają nam pozytywnie patrzeć w przyszłość i z entuzjazmem podejmować kolejne wyzwania, jakie niesie nowy rok akademicki i nowe 25-lecie.

Naszym celem jest, aby Wyższa Szkoła Ekologii i Zarządzania prężnie rozwijała się na rynku edukacyjnym w Polsce i za granicą. Z dużą satysfakcją odnotowujemy, że zainteresowanie kandydatów podjęciem studiów w naszej uczelni stale utrzymuje się na wysokim poziomie. Dziękujemy za zaufanie, jakim nas obdarzają podejmując studia. Postaramy się go nie zawieść. 